\title{
PERFORMANCE PROPERTIES OF KNITTED FABRICS PRODUCED FROM rPET AND COTTON/rPET BLENDED VORTEX AND RING YARNS
}

\section{DOI: 10.35530/TT.2021.32}

\section{A. Oruç*, Y. Arıkan, E. İlanbey, K. Özşahin}

MEM Tekstil San. Ve Tic. A.Ş., Kahramanmaraş/Turkey

(E-mail: aoruc@memtextile.com, kaliteguvence@memtextile.com, arge1@memtextile.com, arge2@memtextile.com)

\begin{abstract}
An awareness of environmental issues is crucial for textile engineering due to increasing consumption of textile fibres. In addition, levels of pollution are ever increasing due to single use polymeric packaging materials in our daily life. Single use polymeric packaging materials, such as PET beverage bottles, have impacts on the consumption of raw materials and energy, on the contamination of our water and atmosphere, on human health, on global climate change. In this point of view, the ability of the textile producers to recycle the disposed PET beverage bottles into textile products has a critical importance. In this study, performance properties of knitted fabrics produced from rPET and cotton/rPET blended vortex and ring yarns are investigated to figure out the reproducibility of environmentally friendly textile products. For this aim, 100\% rPET, 50-50\% rPET-Co and 50-50\% VPET-Co yarns were produced by Vortex and Ring Spinning technologies with same yarn number as Ne 30/1. Then the knitted fabric samples were produced from these sample yarns and the fabrics were dyed. Dimensional stability, bursting strength and pilling resistance properties of the fabrics were examined. Dimensional stability properties of rPET used fabrics were found to be similar with the ones which VPET used. Pilling resistance and bursting strength of the sample fabrics were close to each other that rPET usage does not demonstrate any disadvantage. Consequently, rPET fibre usage instead of VPET fibre is found to be appropriate.
\end{abstract}

Keywords: knitted fabric; r-PET yarn; recycle; ring spinning; vortex spinning

\section{INTRODUCTION}

Economic and population growth, industrialization in the world together causes an increase in the amount of waste. As a consequence of all these, while the more intensive use of natural resources is inevitable, the wastes created by the ever-increasing consumption tendency have reached the huge amounts that threaten the environment and human health due to their quantity and harmful contents [1,2]. The most favourable packaging material is polyethylene terephthalate (PET) is versatile owing to its transparent color, lightweight, strength, food safe, inexpensive price, fully recyclability etc. In addition to all these advantages, PET as a waste material takes up considerable space in nature and needs to be recycled for the disposal of these wastes. In this regard, recycling enables conservation of raw materials, reduce energy use in order to produce virgin PET and reduce greenhouse gas emissions. Today, PET is the most widely recycled plastic in the world. Eco-friendly products obtained by recycling of PET are mainly used as textile fibres [3]. In 
the literature there are some studies which deal with rPET fibre usage in yarn and fabric production [3-12].

\section{MATERIALS AND METHODS}

In this study, it is aimed to compare the performance properties of knitted fabrics which are produced from Regenerated Polyester (rPET) and blends of Virgin Polyester (VPET) and rPET with Cotton (Co). The PET fibre and cotton fibre properties used in the study are given in table 1 and table 2, respectively.

Table 1. Properties of PET fibres used in the study

\begin{tabular}{|l|c|c|}
\hline Characteristics & rPET & VPET \\
\hline Fibre linear density (dtex) & 1.3 & 1.3 \\
\hline Fibre length (mm) & 38 & 40 \\
\hline Fibre strength (g/den) & 6 & 6.95 \\
\hline
\end{tabular}

Table 2. Properties of cotton fibres used in the study

\begin{tabular}{|l|c|c|}
\hline Characteristics & Vortex & Ring \\
\hline Fibre fineness (mic.) & 4.57 & 4.20 \\
\hline Fibre length (mm) & 29.9 & 30.4 \\
\hline Fibre strength (g/tex) & 32.5 & 25.6 \\
\hline
\end{tabular}

In this study, 100\% rPET, 50-50\% rPET-Co and 50-50\% VPET-Co yarns were produced by Vortex and Ring Spinning technologies with same yarn number as Ne 30/1. The unevenness, imperfections and hairiness parameters were tested by USTER Tester by taking samples from 5 bobbins. Strength and breaking elongation parameters were tested by USTER Tensojet. Yarn quality parameters are given in table 3.

Table 3. Quality parameters of the sample yarns

\begin{tabular}{|c|c|c|c|c|c|c|}
\hline \multirow[b]{2}{*}{ Parameter } & \multicolumn{3}{|c|}{ Ring } & \multicolumn{3}{|c|}{ Vortex } \\
\hline & $\begin{array}{l}100 \% \\
\text { rPET }\end{array}$ & $\begin{array}{l}50-50 \% \\
\text { rPET-Co }\end{array}$ & $\begin{array}{c}50-50 \% \\
\text { VPET-Co }\end{array}$ & $\begin{array}{l}100 \% \\
\text { rPET }\end{array}$ & $\begin{array}{l}50-50 \% \\
\text { rPET-Co }\end{array}$ & $\begin{array}{c}50-50 \% \\
\text { VPET-Co }\end{array}$ \\
\hline U (\%) & 11.07 & 10.63 & 10.15 & 11.54 & 11.64 & 10.98 \\
\hline $\mathrm{CVm}$ & 14.00 & 13.43 & 12.85 & 14.55 & 14.67 & 13.83 \\
\hline Thin-50\%/km & 9.5 & 2.5 & 0.5 & 42.5 & 32.5 & 20.5 \\
\hline Thick $+50 \% / \mathrm{km}$ & 53.5 & 58 & 43 & 46 & 61.5 & 40 \\
\hline Neps $+200 \% / \mathrm{km}$ & 78 & 65 & 58.5 & - & - & - \\
\hline Neps $+280 \% / \mathrm{km}$ & - & - & - & 3 & 4 & 3 \\
\hline Hairiness & 6.14 & 6.27 & 5.93 & 3.55 & 4.16 & 4.27 \\
\hline Strength (cN/tex) & 17.61 & 14.07 & 18.62 & 16.64 & 13.70 & 17.25 \\
\hline Breaking elongation (\%) & 10.52 & 5.66 & 7.19 & 9.09 & 5.84 & 6.94 \\
\hline
\end{tabular}

The knitted fabric samples were produced from the sample yarns by a 32 inches diameter and 28 fein single jersey circular knitting machine. Then, the fabric samples were dyed. 100\% Polyester fabric samples and 50-50\% Polyester-Cotton fabric samples were dyed according to the processes given in figure 1 and 2, respectively. 


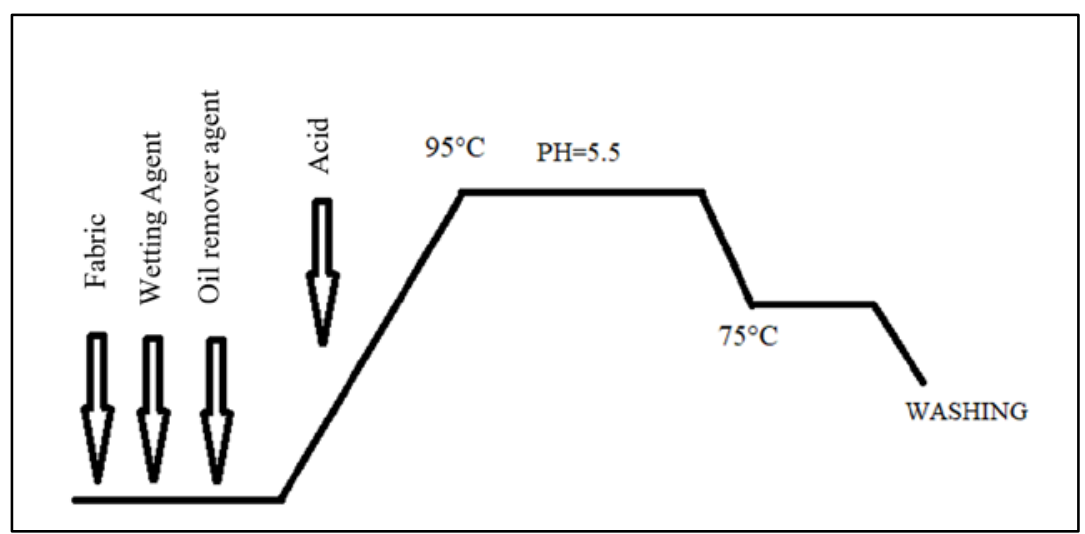

Figure 1. Dyeing curve for $100 \%$ Polyester fabric samples

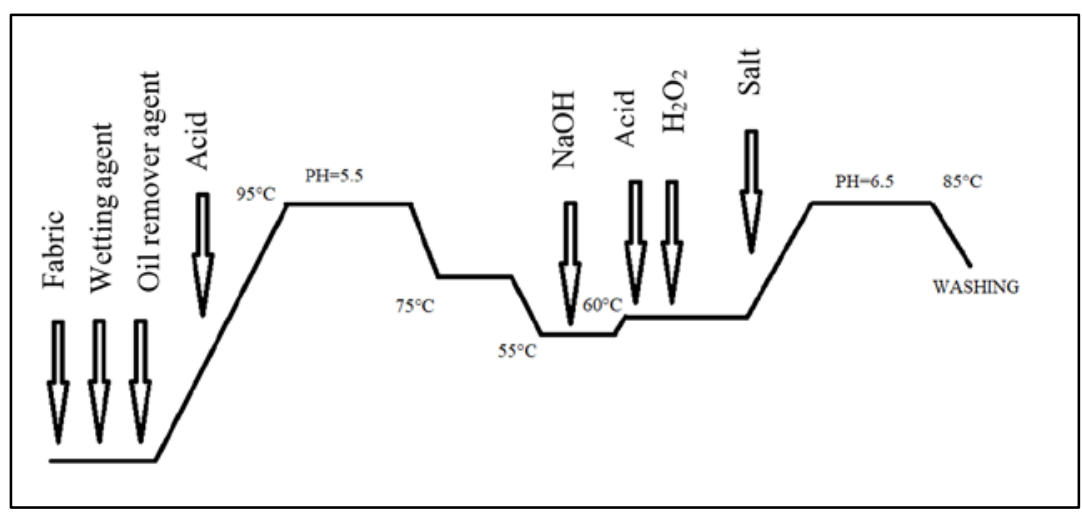

Figure 2. Dyeing curve for Polyester-Cotton blended fabric samples

All fabric samples were conditioned according to TS EN ISO 139 [13] before the tests and measurements. The tests were performed in the standard atmosphere of $20 \pm 2^{\circ} \mathrm{C}$ and $65 \pm 4 \%$ relative humidity. Fabric structural parameters namely; fabric mass, loop density and loop length properties of the dyed samples were determined according to standards of TS EN 12127 [14], TS EN 14971 [15] and TS EN 14970 [16], respectively. The fabric structural parameters are given in table 4 .

Table 4. Structural parameters of sample fabrics

\begin{tabular}{|c|c|c|c|c|c|c|}
\hline \multirow[b]{2}{*}{ Parameter } & \multicolumn{3}{|c|}{ Ring } & \multicolumn{3}{|c|}{ Vortex } \\
\hline & $\begin{array}{l}100 \% \\
\text { rPET }\end{array}$ & $\begin{array}{l}50-50 \% \\
\text { rPET-Co }\end{array}$ & $\begin{array}{c}50-50 \% \\
\text { VPET-Co }\end{array}$ & $\begin{array}{l}100 \% \\
\text { rPET }\end{array}$ & $\begin{array}{c}50-50 \% \\
\text { rPET-Co }\end{array}$ & $\begin{array}{c}50-50 \% \\
\text { VPET-Co }\end{array}$ \\
\hline Fabric mass $\left(\mathrm{g} / \mathrm{m}^{2}\right)$ & 151 & 161 & 173 & 153 & 185 & 174 \\
\hline $\begin{array}{l}\text { Number of courses } \\
\text { (loops/cm) }\end{array}$ & 18 & 21 & 21 & 20 & 23 & 21 \\
\hline $\begin{array}{l}\text { Number of wales } \\
\text { (loops/cm) }\end{array}$ & 14 & 14 & 15 & 15 & 14 & 14 \\
\hline Loop length (mm) & 3 & 2.8 & 2.8 & 3 & 2.8 & 2.8 \\
\hline
\end{tabular}

Dimensional stability and skewness performance after home laundering were determined according to the standards of TS EN ISO 6330 [17] and AATCC 179 [18], respectively. In addition, bursting strength and pilling resistance of the samples were tested according to the standards of TS EN ISO 13938-2 [19] and TS EN ISO 12945-2[20], respectively. 


\section{RESULTS AND DISCUSSIONS}

\subsection{Dimensional Stability and Skewness After Home Laundering}

Dimensional stability of the fabric samples produced from ring yarns and vortex yarns are given in figure 3 and figure 4, respectively.

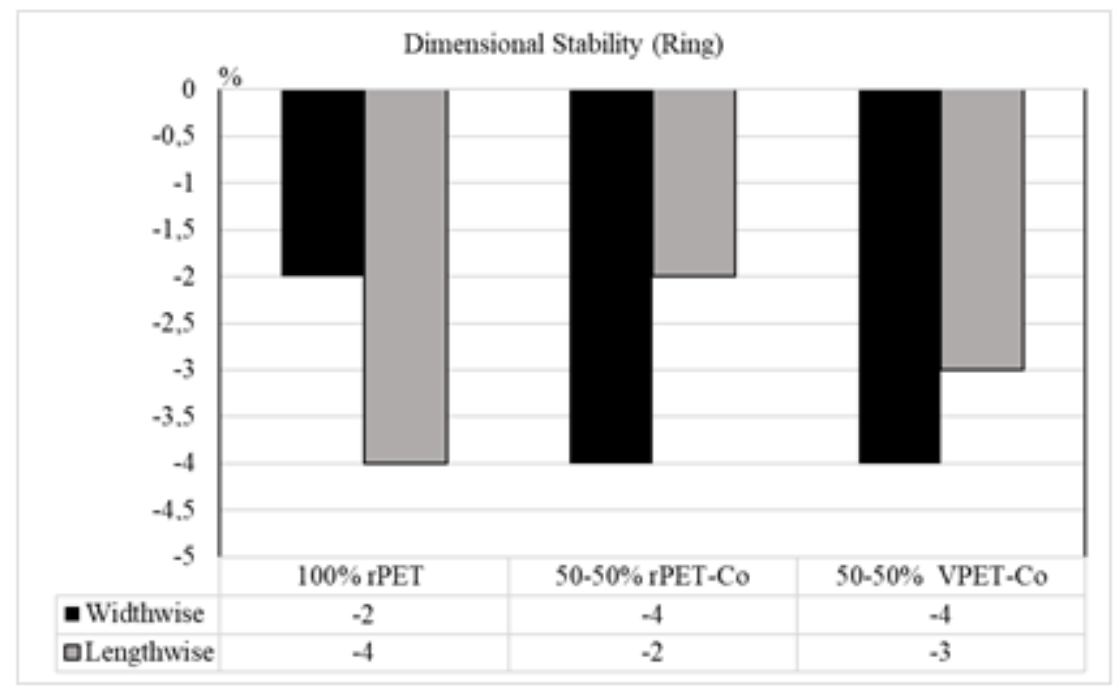

Figure 3. Dimensional stability of the ring yarn samples

It can be seen from figure 3 that the dimensional stability results of all fabric samples are below the commercial acceptability limits (5\%). For ring yarn samples 50-50\% rPET-Co and $50-50 \%$ VPET-Co samples show very similar dimensional stability results. So, it can be concluded that usage of rPET instead of VPET for widely used 50-50 PET-Co blend single jersey fabrics provide a similar fabric performance regarding the dimensional stability after home laundering. With respect to $100 \%$ rPET sample, it is seen that dimensional change values in width wise and lengthwise direction are contrary to other samples. This situation may be attributed to the usage of $50 \%$ cotton fibre.

Dimensional change results below commercial acceptability limits (5\%) are observed for vortex yarn samples similar with ring samples. Figure 4 exhibits that the usage of rPET fibre instead of VPET causes an increase for width wise shrinkage. On the other hand, lengthwise direction shrinkage decreases by the use of rPET fibre instead of VPET. This is a very important result to keep in mind during the production of rPET blended fabrics that some precautions may be taken during commercial production. Also, it can be concluded that the $100 \%$ rPET vortex samples has a more dimensionally stable fabric structure than other samples.

According to the skewness after home laundering results, all fabric samples provided no skewness. So, it can be concluded that usage of rPET fibre instead of rPET has no disadvantage regarding the skewness performance. 


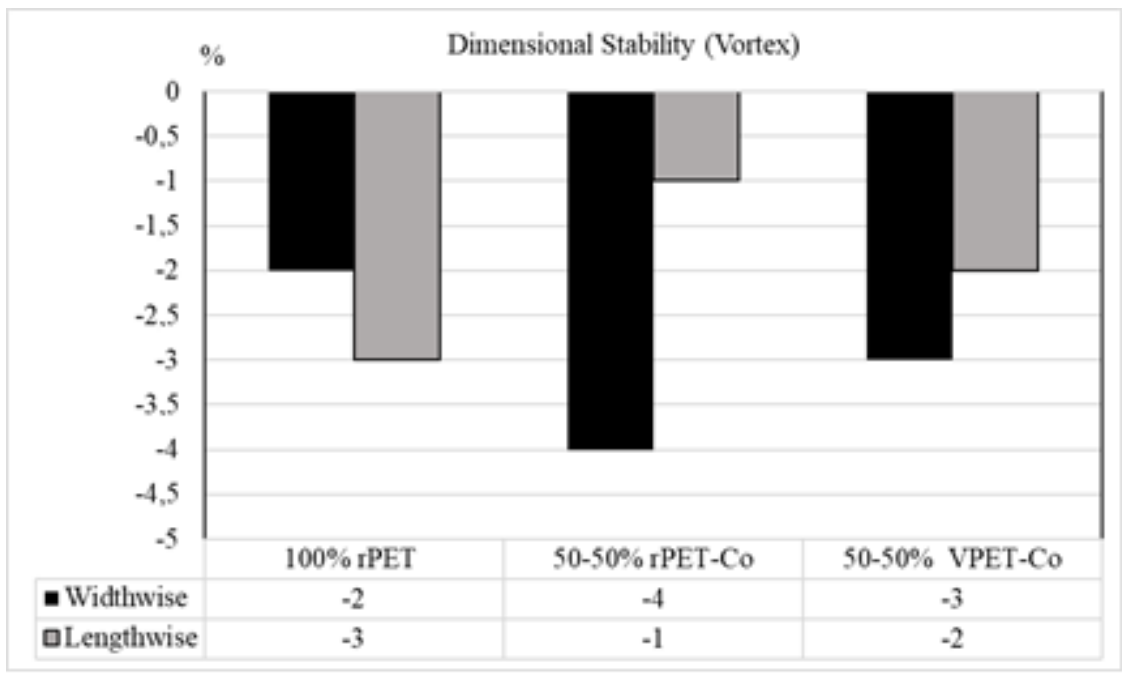

Figure 4. Dimensional stability of the vortex yarn samples

\subsection{Bursting Strength}

Bursting strength test results of the samples are given in figure 5.

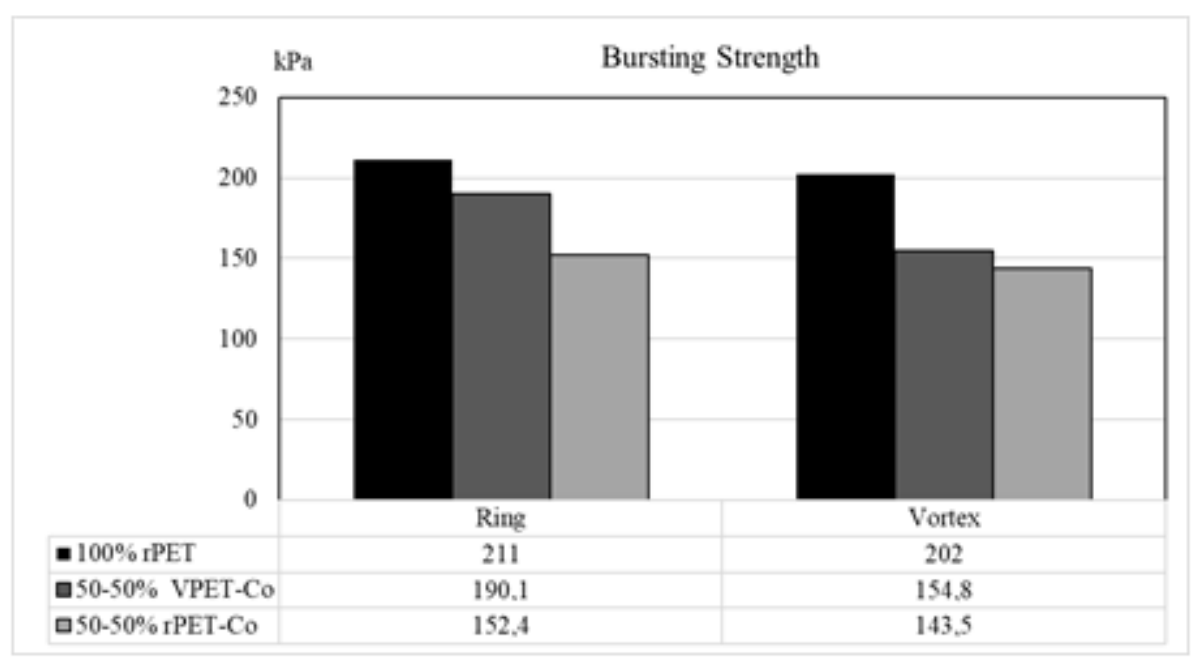

Figure 5. Bursting strength test results of the samples

Figure 5 exhibits the bursting strength values of the samples that the highest bursting strength value is obtained by the $100 \%$ rPET samples for both spinning technologies due to the higher fibre strength of rPET than cotton. 50-50\% VPET-Co samples have higher bursting strength in comparison to 50-50\% rPET-Co samples for both spinning technologies. This situation can be attributed the higher fibre strength of VPET fibre than rPET fibre. On the other hand, it can be seen that the difference between 50-50\% VPET-Co and $50-50 \%$ rPET-Co samples is lower for vortex samples. So, it can be concluded that yarn structure that is obtained by vortex spinning technology may compensate the decrease in bursting strength of the fabrics.

\subsection{Pilling Resistance}

Pilling resistance of the samples are given in table 5. It can be seen that ring yarn samples provide higher pilling tendency than vortex samples. This situation arises from the higher number of protruding fibres ends from yarn structure in ring spinning technology 
than vortex yarn. In vortex spinning technology, there is a group of fibres that provides wrapping around the yarn body. By this way, the number of protruding yarns ends from yarn body is decreased. The fabrics that are produced from ring spun yarns have hairier surface that causes pilling. In addition, it can be seen that usage of rPET fibre instead of VPET cause a slight decrease in pilling resistance for both ring yarn sample. With respect to vortex spinning, rPET usage instead of VPET results in enhancing the pilling resistance surprisingly.

Table 5. Pilling resistance of sample fabrics

\begin{tabular}{|l|c|c|}
\hline \multicolumn{1}{|c|}{ Fibre composition } & Ring & Vortex \\
\hline 100\% rPET & $1 / 2$ & $2 / 3$ \\
\hline $50-50 \%$ rPET-Co & $1 / 2$ & $3 / 4$ \\
\hline $50-50 \%$ VPET-Co & 2 & $2 / 3$ \\
\hline
\end{tabular}

\section{CONCLUSION}

Increasing the rPET usage in textile production is an important issue and also a critical responsibility of commercial textile mills. Owing to this environmental responsibility, in this study it is aimed to investigate the reproducibility of rPET yarns and fabrics produced thereof by the most widely used spinning technologies as ring and vortex spinning. As a result of yarn production, it is seen that rPET and rPET-Co blended yarns have a good level of quality parameters for both spinning technologies except the yarn strength of rPET-Co blended yarns. Also, single jersey knitted fabrics were produced and dimensional stability, bursting strength and pilling resistance properties were demonstrated. As a result of fabric performance tests, it can be concluded that with respect to pilling resistance and skewness rPET usage do not provide any negative effect for both ring and vortex spinning technologies. Dimensional change values of all fabric types used in the study are below the commercially acceptable limits. Regarding the bursting strength performance, the decrease caused by usage rPET usage may be compensated by using vortex spinning technology instead of ring spinning. Consequently, by the important know-how gained by this study, it can be concluded that it is possible for textile mills to produce environmentally friendly rPET knitted fabrics commercially.

\section{REFERENCES}

[1] Tayyar, A.E., Üstün, S., Usage of Recycled PET. In: Pamukkale University, Journal of Engineering Sciences. 2010, 16, 53-62

[2] European Commission DG ENV, Plastic waste in the environment , 2011, Available at: http://ec.europa.eu/ environment/waste/studies/pdf/plastics.pdf [Accessed on June 2021]

[3] Sarı̆ğlu, E., Kaynak, H.K., PET bottle recycling for sustainable textiles. In: Polyester Production, Characterization and Innovative Applications, InTech Publishing, 2018, ISBN: 978953-51-3882-2, Print ISBN: 978-953-51-3881-5, doi: 10.5772/intechopen.69941

[4] Yuksekkaya, E.M., Celep, G., Dogan, G., Tercan M., Urhan B., Comparative study of physical properties of yarns and fabrics produced from virgin and recycled fibers, In: Journal of Engineered Fibers and Fabrics, 2016, 11, 2, 68-76

[5] Inoue, M., Yamatomo, S., Performance and durability of woven fabrics including recycled PET fibers, In: Journal of Textile Engineering, 2004, 50, 2, 25-30 
[6] Rajamanickam, S., Vasudevan, K., Study of Antibacterial Activity of Chitosan on Lyocell and Recycled Poliester Yarns, In: International Journal of Innovative Research in Science Engineering and Technology, 2014, 3, 2, 9480-9486

[7] Sarığlu, E., Ecological Approaches in Textile Sector: The Effect of r-PET Blend Ratio on Ring Spun Yarn Tenacity, In: Periodicals of Engineering and Natural Sciences, 2017, 5, 2, 176-180

[8] Nohut, S., Sarioglu, E., Yayla, O., Kaynak, İ., Vuruskan, D., Ring Ĕ̈irme Yöntemi ile Üretilen Geri Dönüşüm Poliester (r-PET) Karışımlı Ípliklerin Karakterizasyonu, At: $3^{\text {rd }}$ International Mediterranean Science and Engineering Congress, 2018, 971-975

[9] Sarioğlu E., An investigation on performance optimization of r-PET/cotton and v-PET/cotton knitted fabric, In: International Journal of Clothing Science and Technology, 2019, 31, 1, 439-452

[10] Uyanık, S., A study on the suitability of which yarn number to use for recycle poliester fiber, In: The Journal of the Textile Institute, 2019, 110, 7, 1012-1031

[11] Sarioglu, E., Vuruskan, D., Yayla, O., Satil, E.A., Çelikten, E., Investigation of yarn properties produced from $100 \%$ recycled poliester $(r-P E T)$ by different spinning systems, At: The International Conference of Materials and Engineering Technologies, 2019, 450-456

[12] Sarioglu, E., Nohut, S., Vuruşkan, D., Yayla, O., Production and characterization of recycled poliester (r-PET) blend vortex and ring spun yarns, In: The Journal of The Textile Institute, 2020, $111,12,1705-1712$

[13] TS EN ISO 139 Tekstil - Şartlandırma ve deney için standart ortamlar

[14] TS EN 12127 Tekstil-Kumaşlar-Küçük numuneler kullanarak birim alan başına kütlenin tayini

[15] TS EN 14971 Tekstil- Örülmüş kumaşlar- Birim uzunluk ve birim alan başına örgü ilmeği sayısının tayini

[16] TS EN 14970 Tekstil- Örülmüş kumaş- Tek iplikli örme kumaşlarda örgü ilmeği ve iplik doğrusal yoğunluğunun tayini

[17] TS EN ISO 6330 Tekstil- Tekstil deneyleri için- Ev tipi çamaşır makinesi ile yıkama ve kurutma işlemleri

[18] AATCC Test Method 179 Skewness Change in Fabric and Garment Twist Resulting from Automatic Home Laundering

[19] TS EN ISO 13938-2 Tekstil-Kumaşların patlama özellikleri - Bölüm 2: Patlama mukavemetinin ve patlama gerilmesinin tayini için pnömatik metot

[20] TS EN ISO 12945-2 Tekstil - Kumaşlarda yüzey boncuklanması, tüylenmesi ve matlaşması yatkınlığının tayini - Bölüm 2: Geliştirilmiş Martindale metodu 